\title{
Covid-19: UK death toll overtakes Italy's to become worst in Europe
}

\author{
Elisabeth Mahase
}

The BMJ

The UK's death toll from covid-19 has exceeded 32 000, making it the worst affected country in Europe, latest figures show. ${ }^{1}$

Provisional data from England and Wales reported 29710 deaths related to the virus up to 2 May. Added to the deaths in Scotland ${ }^{2}$ (2272 as of 26 April) and Northern Ireland ${ }^{3}$ (393 as of 24 April), this brings the UK's death toll to 32 313. The UK has overtaken Italy (29 029) in terms of the total confirmed death toll but also in deaths per million population, as the UK now reports 486 deaths per million population, compared with 485 in Italy.

Joshua Moon, research fellow in sustainability research methods at the Science Policy Research Unit at the University of Sussex, said, "We need to be considering not just Italy but other countries in Europe and comparing the testing, contact tracing, lockdown, and isolation by each of the countries. By widening our scope to not just the data race for who did 'better' but to how they did 'better,' we can learn to better respond now and in the future."

However, David Spiegelhalter, chair of the Winton Centre for Risk and Evidence Communication at the University of Cambridge, said, "I think we can safely say that none of these countries are doing well, but this is not Eurovision, and it is pointless to try and rank them. For example, apparently around half of Belgium's deaths are people in care homes who have not been tested, and these would not feature at all in the daily UK figures."

Belgium has reported 8016 deaths, equal to 702 per million population. However, unlike the UK, this includes suspected cases rather than only those confirmed through testing.

Spiegelhalter argued that the "one thing we can be certain of is that all these numbers are substantial underestimates of the true number who have died from covid-19, and an even bigger underestimate of the number who have died because of the epidemic and the measures taken against it."

\section{Care homes}

The Office for National Statistics' latest weekly report on all registered deaths showed a decrease of 354 deaths in the week ending 24 April from the previous week's total (from 22351 to 21 997). However, the total was still 11539 higher than the five year average for that week.

On covid-19, the report showed 8237 deaths in the week ending 24 April that mentioned the virus. This was $37.4 \%$ of all deaths, a decrease of 521 from the previous week's total (39.2\% of all deaths).
The total number of deaths from all causes in care homes was 7911 in that same week, which is 595 higher than the previous week, and the total number of deaths in hospital was 8243 , a decrease of 1191 .

Looking more closely at care homes, the report showed an additional 2379 deaths from covid-19 (of 6057 total care home deaths), up from 1873 (of 5497 deaths) the week before.

Sarah Scobie, the Nuffield Trust's deputy director of research, said that the social care sector had now become the "epicentre of the covid-19 pandemic in this country ... We are now seeing almost as many deaths in care homes as hospitals, which will be putting an incredible amount of strain on overburdened care services."

Sarah Deeny, assistant director of data analytics at the Health Foundation, said, "The numbers continue to reflect the fact that care homes are particularly vulnerable to outbreaks of infectious diseases like covid-19. While testing and isolation are important, they may not alone be enough to tackle the ongoing transmission.

"PPE [personal protective equipment] for care workers is vital, as residents will continue to need daily hands-on care from staff who may be infected with the virus but asymptomatic, and symptoms may be more difficult to identify in patients with dementia."

\section{Non covid-19 deaths}

Meanwhile, James Naismith, director of the Rosalind Franklin Institute, emphasised that excess deaths had occurred this year that were not identified as covid-19.

He said, "We urgently need to identify the cause of these deaths. There are many plausible theories as to their cause; however, we need real data on this urgently. As we go forward, we want to minimise all deaths, not just those tagged as covid-19."

Naismith added that it was important to fully understand the impact of each measure introduced to combat covid-19, as "the virus has not gone away, and its potential to spread rapidly and overwhelm the healthcare system is likely to be undiminished."

1 Office for National Statistics. Deaths registered weekly in England and Wales, provisiona: week ending 24 April 2020. 5 May 2020. https://www.ons.gov.uk peoplepopulationandcommunity/birthsdeathsandmarriages/deaths/bulletins/ deathsregisteredweeklyinenglandandwalesprovisional/weekending24april2020.

2 National Records of Scotland. Deaths involving COVID-19, week 17-20 to 26 April. 29 Apr 2020. https://www.nrscotland.gov.uk/news/2020/deaths-involving-covid-19-week-1720th-to-26th-april. 
3 Northern Ireland Statistics and Research Agency. Deaths registered in Northern Ireland-weekly statistics. Provisional statistics week ending 24 April 2020 (week 16). 1 May 2020. https://www.nisra.gov.uk/sites/nisra.gov.uk/files/publications/Deaths\% 20Registered\%20in\%20N1\%20-\%20Week\%2016\%20-\%202020.pdf.
Published by the BMJ Publishing Group Limited. For permission to use (where not already granted under a licence) please go to http://group.bmj.com/group/rights-licensing/ permissions 